\title{
House vote to kill SSC reflects squeeze that budget deficit puts on all research
}

Washington. Last week's vote by the US House of Representatives to kill the Superconducting Super Collider (SSC) surprised both supporters and opponents of the $\$ 8,500$ million project. As a result, neither politicians nor scientists know whether the vote is a temporary setback or a fatal blow to the proton-antiproton accelerator being built in Texas.

Nevertheless, the impact of the 232:181 vote to eliminate all but $\$ 34$ million of the $\$ 650$ million requested for the fiscal year beginning on 1 October is being felt far beyond the high-energy physics community. Some scientists believe that it signifies a lack of support for any costly basic research project that does not contribute relatively quickly to public health or economic well-being. Others say that the vote was merely the first opportunity for Congress to show that it is serious about reducing the $\$ 400,000$-million deficit since members defeated a proposed amendment to the US constitution two weeks ago that would have required them to adopt a balanced budget each year.

What everyone agrees upon is that Congress is almost certain to reduce the sizeable increases for research proposed by the president, George Bush, in his 1993 budget. In particular, officials at the National Science Foundation (NSF) have abandoned all hope for an 18 per cent increase, the US National Aeronautics and Space Administration (NASA) fears for the future of its space station Freedom and the US National Institutes of Health (NIH) would be pleased with a budget that allows them to keep pace with inflation.

The source of this pessimism is a 1990 agreement that limited annual increases in federal spending for the next five years. Research has so far managed to escape the worse effects of that agreement, in part because of the administration's strong support for most areas of basic science and in part because Congress has given to basic science a good portion of 'new' money it found over the past two years.

That money no longer exists, and the relevant category for science (known as domestic discretionary spending) is being squeezed by other programmes with larger constituencies or greater political clout. For example, Bush had proposed nearly $\$ 1,000$ million in increased spending for NASA and NSF next year. But the subcommittee that funds the two agencies also allocates money for veterans' affairs, for which Bush is also seeking another $\$ 1,000$ million. When the subcommittee looked at its yearly allotment, it found that it had money for only half the increase that the president wanted. Forced to choose, the members took the political route; the increase in science programmes would be cut to a quarter of the president's request, while medical care for veterans would receive two-thirds of its increase. That distribution could well be changed in the weeks to come, however, as the bill moves through both houses of Congress.

Because Congress has so little room to manoeuvre, this year's federal budget is much more likely than in the past to resemble the president's initial request submitted in January. That poses a special problem for NIH. In recent years, legislators have added liberally to the president's requested increase. But this year NIH must compete with equally popular pre-college education programmes for a pot that is not big enough for full increases in one, much less both. Congressional staff members say that NIH will be lucky to receive even the president's request - an increase of about $\$ 440$ million, or five per cent, which matches the rate of inflation in the cost of biomedical goods and services.

With respect to the SSC, there are two versions of what is likely to happen next. In the first, the Senate would also vote to eliminate funding for the SSC and the project would be dead. In the second, the House would be persuaded to change its mind in conference with the Senate after the Senate voted sufficient funds to keep the project alive. A subcommittee of the House two weeks earlier voted to hold the SSC to its current level of $\$ 484$ million, and that figure is believed to be the largest possible amount that could emerge from the Congress.

In the meantime, the vote demonstrates that the prospects for the SSC are far gloomier than had been thought. Last year, an attempt to kill the project failed by 87 votes, and neither side expected that margin to change very much in last week's showdown vote. Opponents took credit for having cast doubt, in a series of hearings, on the government's ability to manage the project properly and hold down costs, and they feel that the tide has run out on the SSC.

"Even if the Senate succeeds in saving it this year", says Dan Pearson, an aide to one of the collider's harshest critics, US Representative Sherwood Boehlert (Republican, New York), "there will be a lot of fresh faces in Congress next year who have no track record [of support for the project] to defend and who have promised their constituents that they will balance the budget. I don't see how it can make a comeback."

Jeffrey Mervis \& Christopher Anderson 